\title{
Effect of coal fly ash and vermicompost amendment on soil earthworm and nematode count, and change in soil carbon pool in rice nursery
}

SANAT KUMAR DWIBEDI ( $\nabla$ sanatdwibedi@rediffmail.com )

Odisha University of Agriculture and Technology https://orcid.org/0000-0003-2093-7397

SANJAT KUMAR SAHU

Sambalpur University

JAYANTA KUMAR MAHALIK

Odisha University of Agriculture and Technology

MANORAMA BEHERA

Soil Testing Laboratory, Odisha

\section{Research Article}

Keywords: carbon pool, earthworm, fly ash, nematode, rice nursery, vermicompost

Posted Date: May 20th, 2021

DOI: https://doi.org/10.21203/rs.3.rs-513883/v1

License: (9) This work is licensed under a Creative Commons Attribution 4.0 International License.

Read Full License 


\section{Abstract}

Fly ash (FA) as a byproduct from the coal-fired power plants needs timely, effective, productive and safe disposal. Its application to soil at lower concentration is advocated by many researchers due to its soil ameliorative properties. Combined application of FA along with organic substrates such as farm yard manure, compost, and microbial culture has positive influence on soil biota and crop performance. But the xenobiotic effect of FA in presence of vermicompost (VC) has not yet been studied fully. The present investigation was carried out in western Odisha, India with native soil, FA and VC at $0 \%, 20 \%, 40 \%, 60 \%$, $80 \%$ and $100 \%$ combinations (by weight) to study their effects on earthworm and nematode count, and change in soil carbon pool in rice nursery. The experiment was laid out in a factorial complete randomized design with three replications. The earthworm and nematode population at 40 DAS of rice was positively influenced by the concentration of VC in rhizosphere of rice nursery but FA addition affected earthworm survivability to an extent that no earthworm was found with more than $20 \%$ FA. Rhabditis terricola and Dorylaimids in the rhizosphere of rice nursery was also positively linked with VC concentration while FA had antagonistic effects. Absence of nematodes and earthworm at higher concentration of FA could be linked to xenobiotic effects of FA. Mild addition ( $20 \%$ each) of FA and VC to native soil could increase in carbon stock to the maximum extent due to combined effect of larger surface area of FA and minimized microbial activity limiting respirational carbon loss.

\section{Introduction}

Burning of fossil fuels for yielding energy is an inevitable practice in the race for economic development across the globe. Coal-fired power plants are the main source of energy in many developed and developing countries. Combustion of pulverized sub-bituminous coal (lignite) in the furnace generate byproducts such as fly ash (FA), bottom ash and boiler slag that need timely, effective, productive and safe disposal; particularly FA that accounts for the maximum volume. The so called problematic 'solid waste' has now gained the status of 'valuable wealth' due to innovative practice of its use in agriculture, construction, land filling, etc. This amorphous ferro-alumino silicate with most essential plant elements except organic carbon, nitrogen and phosphorous (Tripathy and Sahu 1997) could very well be used in agriculture at lower concentration. Its addition alters physicochemical properties of soil and acts as soil conditioner or modifier (Kalra et al., 1998). FA improves soil bacteria count and enzyme activity of dehydrogenase, urease and alkaline phosphatase which are beneficial for plant growth (Yeledhalli et al. 2007). Presence of heavy metals in FA is a great concern. Many researchers have used it in addition to farm yard manure, compost, microbial culture, etc. in agricultural crops. Researchers recommend for its application in lower concentration as soil microbial population and nutrient availability are affected at higher concentrations. Attempts have already been made to study the composting behaviour of earthworms at varying concentrations of FA to prepare vermi-ash. However, use of FA and vermicompost (VC) in agricultural field has not yet been studied much.

An investigation into the literature on the effects of FA and VC on soil biota, particularly the nematode and earthworm, indicated reduction in nematode population with $40 \%$ addition of FA in tomato crop due 
to nematicidal effect of FA (Ahmad and Alam 1997; Singh et al. 2011). FA has shown inhibitory effects on root-knot nematodes (Tarannum et al. 2001). Potato cyst nematode (Renco and Kovacik 2015) and plant parasitic nematode (Meloidogyne incognita) population reduced significantly with application of VC but the population of fungivorous and bacterivorous nematodes increased (Munyua et al. 2015).

Rhabditis terricola were found in cocoons of Lumbricus rubellus and Eisenia fetida that failed to hatch after an adequate incubation period. This nematode, previously known as a saprophyte, was found to invade earthworm cocoons and reproduce within, causing extensive productivity losses in earthworm cultures (Taboga 1981). However, results on the effects of simultaneous use of FA and VC at different concentrations on soil biota are very rarely traceable.

Addition of FA provides microclimate to facilitate organic matter humification and formation of stable organic carbon (Ukwattage et al. 2013). Increase in carbon stock of soil in agriculture field with the addition of FA was also noted by Bruce et al. (2009). A major absorption of atmospheric $\mathrm{CO}_{2}$ occurs in presence of oxides and hydroxides of $\mathrm{Ca}$ and $\mathrm{Mg}$ in FA (Palumbo et al. 2004). Carbon also enters into the soil through root exudates (Kell 2012). However, presence or absence of earthworm in soil did not have any effect in mineral fertilised soils but the quality and quantity of soil organic matter were positively influenced by bioturbation in compost-amended soil (Thi Ngo et al. 2012). Oke (2015) has also recommended VC application for increasing the soil organic carbon. With this backdrop, an experiment was conducted to elucidate the effects of FA and VC on earthworm and nematode population, and to monitor short-term change in carbon pool in the rhizospheric substrate under rice nursery.

\section{Materials And Methods}

\subsection{Experimental site and climate}

The experiment was laid out during March to June 2017 in the West Central Table Land Zone, Sambalpur, Odisha, India $\left(83^{0} 53^{\prime} \mathrm{E}\right.$ and $21^{\circ} 21^{\prime} \mathrm{N}$ ) at $150.75 \mathrm{~m}$ above the MSL, $365 \mathrm{~km}$ away from the Bay of Bengal at the east. No crop was cultivated in the experimental site during last 5 years. This locality is classified as Aw (Koppen and Geiger 1984) and characterized by tropical climate with warm and dry summer and normal to chilling winter with much rainier summers than winters. The long-term average temperature and annual rainfall are $26.8{ }^{\circ} \mathrm{C}$ and $1,638 \mathrm{~mm}$, respectively. The monthly weather parameters during the cropping season (kharif 2017) recorded at the meteorological observatory nearby the experimental site has been depicted in Fig1. A composite soil sample drawn from the experimental site was processed and analysed for physicochemical properties by following procedures mentioned in book.

\subsection{Experimental set up}

Three different substrates i.e. native soil, coal fly ash (henceforth FA) and vermicompost (VC), each at 6 different concentrations i.e. $0 \%, 20 \%, 40 \%, 60 \%, 80 \%$ and $100 \%$ (by weight) were mixed to result 21 treatment combinations (Table 1) that were replicated thrice in box-plots under factorial complete randomized design. No additional chemical or organic fertilizer was supplemented except FA and VC as 
per experimental plan. The FA was procured from the nearby HINDALCO industries Ltd., Sambalpur from the FA pond where all types of coal ash are dumped. The VC was prepared from FYM in poly-tank by engaging Eisenia fetida. The detailed analyses reports of the 3 substrates (soil, FA and VC) at the beginning of the experiment are under Table 2.

A semi-dwarf, non-lodging, non-shattering and medium duration (135 days), high-yielding rice (Oryza sativa L.) cv. Vijetha (MTU-1001) with moderate tillering habit was adopted for conducting this experiment. Foundation seeds of this cultivar were sterilised with $0.1 \% \mathrm{HgCl}_{2}$ for 5 minutes to eliminate fungal infection and then ringed thoroughly with water before soaking in distilled water for 5 hours. The soaked seeds were removed from water and air dried before sowing evenly by a dibbler. After 10 days, excess seedlings were thinned out to keep uniform stand and avoid over-crowding. Two hand weedings (at 20 and 40 DAS) were carried out to facilitate seedling growth. Use of plant protection chemicals was deliberately avoided to safeguard soil biota. Distilled water of equal quantity was applied to each box-plot during the entire nursery period and adequate measures were taken to avoid irrigation water stagnation.

\subsection{Methods of recording observations}

At the end of the experiment, nematode population from the soil sample was studied by following the procedure by combination of Cobb's sieving and decanting technique and modified Baermann's technique (Barker, 1985) and the earthworm population from the soil sample was studied by washing out the soil and counting the number.

Increase in carbon pool of the soil that occurs due to fixing up of the atmospheric $\mathrm{CO}_{2}$ or addition of organic matter or by reduction in the microbial activities can be estimated by using the procedure laid down by Kundu et al. (2007). In this experiment, the initial organic carbon (OC) percentage of each treatment at the beginning of the experiment was used for estimating the corresponding initial OC\% of each treatment combination. The difference in the $\mathrm{OC} \%$ between $30 \mathrm{DAS}$ and the initial values gave rise to the change in $\mathrm{OC} \%$. The $\mathrm{BD}$ of each treatment combination was multiplied with the corresponding $\mathrm{OC}$ ( $\mathrm{mg} \mathrm{kg}^{-1}$ of soil) difference so as to get the carbon pool of the soil.

Mathematically,

Soil organic carbon stock $(\mathrm{SOC})=$

Increase/ decrease of SOC stock due to treatment over the initial stock

Duration / period

\subsection{Statistical analysis}


All data collected were arranged and analysed statistically by following procedures laid down by Gomez and Gomez (1984). One-way ANOVA at 0.05 probability levels was applied assessing the effect of FA and VC amendments on the above parameters by using MS-Excel. In the summary tables of results, the standard error of means (S.Em \pm ) and the value of the critical difference (CD) have been shown to compare the differences among treatment means.

\section{Results And Discussion}

\subsection{Earthworm population}

At 40 DAS, the population of earthworm $\mathrm{m}^{-3}$ was the maximum $(1067.2 \pm 287.7)$ in $\mathrm{S}_{20} \mathrm{~F}_{0} \mathrm{~V}_{80}$ followed by $\mathrm{S}_{60} \mathrm{~F}_{0} \mathrm{~V}_{40}, \mathrm{~S}_{40} \mathrm{~F}_{0} \mathrm{~V}_{60}, \mathrm{~S}_{0} \mathrm{~F}_{0} \mathrm{~V}_{100}, \mathrm{~S}_{20} \mathrm{~F}_{20} \mathrm{~V}_{60}$ and $\mathrm{S}_{60} \mathrm{~F}_{20} \mathrm{~V}_{20}$ in descending order (Table 3). No earthworm was found in rest of the treatment combinations. No earthworm was also found in any treatment combination with FA only but without soil in it. The earthworm population was relatively higher in complete absence of FA compared to those present in the lower level of FA. This could be due to the extreme sensitivity of earthworms to negative effects of FA in absence of soil. Alternatively, the ability of soil in smothering ill effects of FA, only at a lower level (20\%), could be attributed to their survivability in it. The dormant cocoons carried over by the freshly prepared VC are supposed to be the source of earthworms in different treatment combinations.

\subsection{Nematode population}

At 30 DAS, the highest population $\left(32.3 \pm 8.5 \mathrm{~g}^{-1}\right.$ ) of Rhabditis terricola (Fig2.a and 2.b) was in $\mathrm{S}_{0} \mathrm{~F}_{0} \mathrm{~V}_{100}$ followed by $S_{80} F_{0} V_{20}\left(24.7 \pm 4.9 \mathrm{~g}^{-1}\right)$ and $S_{40} F_{0} V_{60}\left(24.3 \pm 6.0 \mathrm{~g}^{-1}\right)$ (Table 3). This species of nematode was not seen in $\mathrm{S}_{0} \mathrm{~F}_{100} \mathrm{~V}_{0}, \mathrm{~S}_{20} \mathrm{~F}_{80} \mathrm{~V}_{0}, \mathrm{~S}_{40} \mathrm{~F}_{60} \mathrm{~V}_{0}$ and $\mathrm{S}_{60} \mathrm{~F}_{40} \mathrm{~V}_{0}$. The population of Dorylaimids (Fig3.a and 3.b) was although maximum in $\mathrm{S}_{40} \mathrm{~F}_{0} \mathrm{~V}_{60}\left(10.3 \pm 4.2 \mathrm{~g}^{-1}\right)$ but at par with the next best combinations $\left(\mathrm{S}_{20} \mathrm{~F}_{0} \mathrm{~V}_{80}\right.$ and $\left.\mathrm{S}_{40} \mathrm{~F}_{20} \mathrm{~V}_{40}\right)$. Not a single specimen of Dorylaimids was found in $\mathrm{S}_{0} \mathrm{~F}_{40} \mathrm{~V}_{60}, \mathrm{~S}_{0} \mathrm{~F}_{60} \mathrm{~V}_{40}$, $\mathrm{S}_{0} \mathrm{~F}_{80} \mathrm{~V}_{20}, \mathrm{~S}_{0} \mathrm{~F}_{100} \mathrm{~V}_{0}, \mathrm{~S}_{20} \mathrm{~F}_{40} \mathrm{~V}_{40}, \mathrm{~S}_{20} \mathrm{~F}_{60} \mathrm{~V}_{20}, \mathrm{~S}_{20} \mathrm{~F}_{80} \mathrm{~V}_{0}, \mathrm{~S}_{40} \mathrm{~F}_{60} \mathrm{~V}_{0}, \mathrm{~S}_{60} \mathrm{~F}_{40} \mathrm{~V}_{0}, \mathrm{~S}_{80} \mathrm{~F}_{0} \mathrm{~V}_{20}$ and $\mathrm{S}_{80} \mathrm{~F}_{20} \mathrm{~V}_{0}$. The population of Rhabditis terricola varied with the concentration of $\mathrm{VC}$ in different treatment combinations. As they are the nematode cocoon feeding parasites their population was likely to differ according to the levels of VC. However, the presence of FA has an adverse effect on its population in-spite of the presence of VC. The plant-parasitic nematode Dorylaimida sps acting as the transmitter of viruses also varies with levels of $\mathrm{VC}$ and $\mathrm{FA}$. However, their maximum presence in $\mathrm{S}_{40} \mathrm{~F}_{0} \mathrm{~V}_{60}$ might be due to synergistic growth environment.

\subsection{Variation in soil carbon pool}

With $20 \%$ substitution of VC by FA i.e. in $\mathrm{S}_{0} \mathrm{~F}_{20} \mathrm{~V}_{80}$, significantly the highest OC\% $(0.45 \pm 0.027)$ was recorded at 30 DAS (Table 3 and Fig4) among all treatment combinations including $100 \%$ VC $(0.306 \pm$ $0.021 \%)$. The $\mathrm{OC} \%$ of native virgin soil $\left(\mathrm{S}_{100} \mathrm{~F}_{0} \mathrm{~V}_{0}\right)$ at 30 DAS was the lowest $(0.018 \pm 0.001)$ without any deviation from its initial status in-spite of raising rice nursery in it and that was ensued by $S_{80} F_{20} V_{0}$ 
$(0.027 \pm 0.002 \%)$. The OC\% of sole FA at 30 DAS was lesser $(0.054 \pm 0.003 \%)$ than the initial content (0.09\%). Relatively higher OC\% with low (20\%) to moderate (40\%) application of FA or soil to VC could be mostly due to higher OC base-status of VC and also due to lesser microbial decomposition during 30 DAS. But, with higher application FA the OC\% reduced significantly mostly due to marginal C contribution from FA. Such type of inverse relation was also observed by Singh et al. (2011) and Sarkar et al. (2012).

Increase in carbon stock with the addition of FA and VC to virgin native soil could be ascribed to increased surface area of substrate due to finer particle size of FA that combined atmospheric $\mathrm{CO}_{2}$, both physically and chemically. This was in agreement with the earlier explanations cited by Zuniga et al. (2016) for carbon dioxide adsorption and Palumbo et al. (2004) for chemical reaction with oxides and hydroxides of $\mathrm{Ca}$ and $\mathrm{Mg}$ present in FA. Furthermore, higher carbon stock could also be due to reduced microbial activities in FA amended substrates that might have minimised decomposition and respiration that ultimately reduced $\mathrm{CO}_{2}$ emission. This is in conformity with the earlier result of Yunusa et al. (2015) and Bruce et al. (2009). On the contrary, negative carbon stock in substrates without VC vis-à-vis in 100\% VC could possibly be due to rapid decomposition of the organic carbon in presence of active saprophytic microorganisms in VC. This was in agreement with the previous report (Anonymous 2008). Lack of buildup of soil microbes in $100 \%$ virgin soil could be the reason for no change in carbon stock.

\section{Conclusion}

The population of earthworm was positively influenced by the concentration of VC in rhizosphere of rice nursery but FA addition affected earthworm survivability to such an extent that no earthworm was found with more than 20\% FA. The population of Rhabditis terricola and Dorylaimids in the rhizosphere of rice nursery was also positively linked with VC concentration while FA had antagonistic effects. In comparison to Rhabditis terricola, Dorylaimida sps had more affinity towards native soil. Absence of nematodes and earthworm at higher concentration of FA could be linked to xenobiotic effects of FA. Mild addition (20\% each) of FA and VC to native soil could increase in carbon stock to the maximum extent due to combined effect of larger surface area of FA that fixed atmospheric $\mathrm{CO}_{2}$ and minimized microbial decomposition of organic matter supplemented through VC and respiration by microbes as well. Chemical reaction with oxides and hydroxides of $\mathrm{Ca}$ and $\mathrm{Mg}$ present in FA could also be ascribed to higher carbon stock at mild addition of FA. But higher concentration FA acted negatively on the carbon pool in the rhizosphere of rice nursery.

\section{Declarations}

Acknowledgements The authors highly acknowledge the supports received from the Sambalpur University, Odisha for conducting such FA remediating and environment regretting research work in the FA rich pocket of the Western Odisha, India.

Author contributions: SKD: Conceptualization, visualization, methodology, formal analysis, analyzed data, writing-original draft. SKS: Review and editing. MB: Soil analysis. 
Funding No external research grant was received for this post graduation dissertation work

Data availability The authors confirm that the data supporting the findings of this study are available within the article.

\section{Compliance with ethical standards}

Ethical approval This work was performed in compliance with ethical standards.

Consent to participate All authors were informed about, and agreed to the protocol.

Consent to publish All authors were allowed to read and approve the final manuscript.

Conflict of interest There is no conflict of interest in relation to this article.

ORCID: https://orcid.org/0000-0003-2093-7397

\section{References}

Ahmad A and Alam MM (1997) Utilization of flyash and Paecilomyces lilacinus for the control of Meloidogyne incognita. Intern J Nemato 7:162-164.

Anonymous (2008) Compost can turn agricultural waste into a carbon sink, thus protecting against climate change. Waste Manag Res https://www.eurekalert.org/pub_releases/2008-02/spucct022208.php. Accessed 9 May 2021

Barker KR (1985). Nematode extraction and bioassays. In: Barker, K.R., Carter, C.C., Sasser, J.N. (Eds.), An Advanced Treatise on Meloidogyne, Vol. 2, Methodology. North Carolina State University Graphics, Raleigh, pp. 19-35.

Bouyoucos GH (1951). A recalibration of the hydrometer for making mechanical analysis of soils. Agron J 43, 438. https://doi.org/10.2134/agronj1951. 00021962004300090005x

Bray RH, Kurtz LT (1945). Determination of total, organic and available forms of phosphorus in soils. Soil Sci 59, 39-45. https://doi.org/10.1097/00010694-194501000-00006

Bruce S, Sims J, Walcott J, Baldock J, Grace P (2009) Soil carbon management and carbon trading. Grain Year Book 1:17-22.

Gomez KA, Gomez AA (1984) Statistical procedures for agricultural research. Second edition. Wiley India pp.200-206.

Jackson ML (1958) Soil Chemical Analysis. Prentice Hall Inc., Englewood Chiffs 213-214. 
Jackson ML (1973). Soil chemical analysis. Prentice Hall of India Private Limited. New Delhi 498p. https://doi.org/10.1002/jpln.19590850311

Kell DB (2012) Large-scale sequestration of atmospheric carbon via plant roots in natural and agricultural ecosystems: why and how. Philoso Trans Royal Soc London Biol Sci 367:1589-1597.

https://doi.org/10.1098/rstb.2011.0244

Koppen W (1884) Translated by Volken, E. and Brönnimann, S. < 'Die Wärmezonen der Erde, nach der Dauer der heissen, gemässigten und kalten Zeit und nach der Wirkung der Wärme auf die organische Welt betrachtet" [The thermal zones of the earth according to the duration of hot, moderate and cold periods and to the impact of heat on the organic world)>. Meteoro Zeitschrift (published 2011), 20 (3): 351-360.

Kundu S, Bhattacharyya R, Prakash V, Ghosh BN, Gupta HS (2007) Carbon sequestration and relationship between carbon addition and storage under rainfed soyabean-wheat rotation in a sandy loam soil of the Indian Himalayas. Soil Till Res 92: 87-95. https://doi.org/10.1016/j.still.2006.01.009

Muhr GR, Dutta NP, Sankarsubramoney HS, Laley VK, Donahue RL (1965). Soil testing in India, U.S.A. for international development mission to India, New Delhi ( $2^{\text {nd }}$ ed.); 33-46.

Munyua L, Thies J, Narla RD, Kimenju JW, Were S, Kioko DM, Roobroek D, Vanieuve B, Agve J (2015) Effect of biochar and vermicompost in suppression of plant parasitic nematodes affecting beans (Phaseolus vulgaris L.) in Western Kenya. In: Synergy in Science: Partnering for solutions. Annual meeting. Nov 15-18. 2015.

Oke OF (2015) Influence of municipal solid waste vermicompost on soil organic carbon stock and yield of Okra (Abelmoschus esculentus Moench) in a Tropical Agroecosystem. J Environ Earth Sci 5(12): 61-66. https://www.iiste.org/Journals/index.php/JEES/article/view/23303. Accessed 9 May 2021

Palumbo AV, Mccarthy JF, Amonettej E, Fisher LS, Wullschleger SD, Daniels WL (2004) Prospects for enhancing carbon sequestration and reclamation of degraded lands with fossil-fuel combustion byproducts. Adv Environ Res 8(3-4): 425. https://doi.org/10.1016/S1093-0191(02)00124-7

Renco M, Kovacik P (2015) Assessment of nematicidal potential of vermicompost tea, and urea application on the potato-cyst nematodes Globora rostochiensis and Globodera pallid. J Pla Prot Res 55(2):187-192. https://doi.org/10.1515/jppr-2015-0025

Sarkar A, Singh A, Agrawal SB (2012) Utilization of fly ash as soil amendments in agricultural fields of North-Eastern Gangetic plains of India: Potential benefits and risks assessments. Bull of the Nat Inst Eco 23: 0-00. https://nieindia.org/Journal/index.php/niebull/article/view/150. Accessed 9 May 2021

Singh S, Gond D, Pal A, Tewary BK, Sinha A (2011) Performance of several crops grown in fly ash amended soil. In: World coal Ash Conference- May 9-12, 2011, Denver, CO, USA. http://www.flyash.info/ 
Subbiah BV, Asija GL (1956). A rapid procedure for the determination of available nitrogen in soils. Cur Sci 25:259-260.

https://www.scirp.org/(S(i43dyn45teexjx455qlt3d2q))/reference/ReferencesPapers.aspx?

ReferencelD=2138694. Accessed 9 May 2021

Taboga L (1981) Rhabditis terricola: An opportunistic nematode parasite of earthworm cocoons. J Invert Patho 38(1): 20-25. https://doi.org/10.1016/0022-2011(81)90029-X. Accessed 9 May 2021

Tarannum A, Khan AA, Diva I, Khan B (2001) Impact of fly ash on hatching, penetration and development of root-knot nematode, Meloidogyne javanica on chickpea (Cicer arietinum L.). Nemato Mediter 29: 215218.

Thi Ngo P, Rumpel C, Doan T, Pascal J (2012) The effect of earthworms on carbon storage and soil organic matter composition in tropical soil amended with compost and vermicompost. Soil Bio Bioche 50: 214-220. https://doi.org/10.1016/j.soilbio.2012.02.037

Tripathy A, Sahu RK (1997) Effect of coal fly ash on growth and yield of wheat. J Environ Bio 18(2): 131135. https://www.osti.gov/etdeweb/biblio/488690. Accessed 9 May 2021

Ukwattage NL, Ranjith PG, Bouazza (2013) The use of coal combustion fly ash as a soil amendment in agricultural lands (with comments on its potential to improve food security and sequester carbon. Fuel 109:400-408. https://doi.org/10.1016/j.fuel.2013.02.016

Walkley AS, Black IA (1934) An examination of the degtjareff method of determining soil organic matter and a proposed modification of the chromic acid titration method. Soil Sci 37, 29-38.

https://doi.org/10.1097/00010694-193401000-00003

Yeledhalli N, Prakash S, Gurumurthy S, Ravi M (2007) Coal fly ash as modifier of physico-chemical and biological properties of soil. Karnat J Agric Sci 20(3):531-534.

Yunusa IAM, Blair G, Zerihun A, Yang S, Wilson SC, Young IM (2015) Enhancing carbon sequestration in soil with coal combustion products: a technology for minimising carbon footprints in coal-power generation and agriculture. Clim Cha 2015, 131(4): 559. https://doi.org/10.1007/s10584-015-1388-0

Zuniga SL, Navarrete C, Cordova LR, Zeppelin LH, Urbina RH (2016) $\mathrm{CO}_{2}$ adsorption on agricultural biomass combustion ashes. Mad Clencia Y Tech 18(4). http://dx.doi.org/10.4067/S0718$221 \times 2016005000053$

\section{Tables}

Table 1 Details of treatment combinations and symbols used 


\begin{tabular}{|c|c|c|c|c|c|}
\hline $\begin{array}{l}\text { Sl. } \\
\text { No. }\end{array}$ & Treatment combinations & $\begin{array}{l}\text { Symbols } \\
\text { used }\end{array}$ & $\begin{array}{l}\text { Sl. } \\
\text { No. }\end{array}$ & Treatment combinations & $\begin{array}{l}\text { Symbols } \\
\text { used }\end{array}$ \\
\hline 1 & $\begin{array}{l}\text { NS }(0 \%)+F A(0 \%)+V C \\
(100 \%)\end{array}$ & $S_{0} F_{0} V_{100}$ & 12 & $\begin{array}{l}\text { NS }(40 \%)+F A(0 \%)+V C \\
(60 \%)\end{array}$ & $\mathrm{S}_{40} \mathrm{~F}_{0} \mathrm{~V}_{60}$ \\
\hline 2 & $\begin{array}{l}\text { NS }(0 \%)+F A(20 \%)+V C \\
(80 \%)\end{array}$ & $\mathrm{S}_{0} \mathrm{~F}_{20} \mathrm{~V}_{80}$ & 13 & $\begin{array}{l}\text { NS }(40 \%)+F A(20 \%)+V C \\
(40 \%)\end{array}$ & $\mathrm{S}_{40} \mathrm{~F}_{20} \mathrm{~V}_{40}$ \\
\hline 3 & $\begin{array}{l}\text { NS }(0 \%)+F A(40 \%)+V C \\
(60 \%)\end{array}$ & $\mathrm{S}_{0} \mathrm{~F}_{40} \mathrm{~V}_{60}$ & 14 & $\begin{array}{l}\text { NS }(40 \%)+F A(40 \%)+V C \\
(20 \%)\end{array}$ & $\mathrm{S}_{40} \mathrm{~F}_{40} \mathrm{~V}_{20}$ \\
\hline 4 & $\begin{array}{l}\text { NS }(0 \%)+F A(60 \%)+V C \\
(40 \%)\end{array}$ & $\mathrm{S}_{0} \mathrm{~F}_{60} \mathrm{~V}_{40}$ & 15 & $\begin{array}{l}\text { NS }(40 \%)+F A(60 \%)+V C \\
(0 \%)\end{array}$ & $\mathrm{S}_{40} \mathrm{~F}_{60} \mathrm{~V}_{0}$ \\
\hline 5 & $\begin{array}{l}\text { NS (0\%) + FA }(80 \%)+\text { VC } \\
(20 \%)\end{array}$ & $\mathrm{S}_{0} \mathrm{~F}_{80} \mathrm{~V}_{20}$ & 16 & $\begin{array}{l}\text { NS }(60 \%)+F A(0 \%)+V C \\
(40 \%)\end{array}$ & $\mathrm{S}_{60} \mathrm{~F}_{0} \mathrm{~V}_{40}$ \\
\hline 6 & $\begin{array}{l}\text { NS }(0 \%)+F A(100 \%)+V C \\
(0 \%)\end{array}$ & $\mathrm{S}_{0} \mathrm{~F}_{100} \mathrm{~V}_{0}$ & 17 & $\begin{array}{l}\text { NS }(60 \%)+F A(20 \%)+V C \\
(20 \%)\end{array}$ & $\mathrm{S}_{60} \mathrm{~F}_{20} \mathrm{~V}_{20}$ \\
\hline 7 & $\begin{array}{l}\text { NS }(20 \%)+F A(0 \%)+V C \\
(80 \%)\end{array}$ & $\mathrm{S}_{20} \mathrm{~F}_{0} \mathrm{~V}_{80}$ & 18 & $\begin{array}{l}\text { NS }(60 \%)+F A(40 \%)+V C \\
(0 \%)\end{array}$ & $\mathrm{S}_{60} \mathrm{~F}_{40} \mathrm{~V}_{0}$ \\
\hline 8 & $\begin{array}{l}\text { Soil }(20 \%)+\text { FA }(20 \%)+ \\
\text { VC }(60 \%)\end{array}$ & $S_{20} F_{20} V_{60}$ & 19 & $\begin{array}{l}\text { Soil }(80 \%)+\text { FA }(0 \%)+\text { VC } \\
(20 \%)\end{array}$ & $\mathrm{S}_{80} \mathrm{~F}_{0} \mathrm{~V}_{20}$ \\
\hline 9 & $\begin{array}{l}\text { NS }(20 \%)+F A(40 \%)+V C \\
(40 \%)\end{array}$ & $\mathrm{S}_{20} \mathrm{~F}_{40} \mathrm{~V}_{40}$ & 20 & $\begin{array}{l}\text { NS }(80 \%)+F A(20 \%)+V C \\
(0 \%)\end{array}$ & $\mathrm{S}_{80} \mathrm{~F}_{20} \mathrm{~V}_{0}$ \\
\hline 10 & $\begin{array}{l}\text { NS }(20 \%)+F A(60 \%)+V C \\
(20 \%)\end{array}$ & $\mathrm{S}_{20} \mathrm{~F}_{60} \mathrm{~V}_{20}$ & 21 & $\begin{array}{l}\text { NS }(100 \%)+F A(0 \%)+V C \\
(0 \%)\end{array}$ & $\mathrm{S}_{100} \mathrm{~F}_{0} \mathrm{~V}_{0}$ \\
\hline 11 & $\begin{array}{l}\text { NS }(20 \%)+F A(80 \%)+V C \\
(0 \%)\end{array}$ & $\mathrm{S}_{20} \mathrm{~F}_{80} \mathrm{~V}_{0}$ & & & \\
\hline
\end{tabular}

N.B.: Native soil (NS and S), fly ash (FA and F) and vermicompost (VC and V)

Table 2 Physicochemical properties of the treatments 


\begin{tabular}{|c|c|c|c|c|}
\hline Parameters & Soil & Coal ash & Vermicompost & Method(s) employed \\
\hline Sand (\%) & 22.4 & 10.4 & 42.4 & \multirow[t]{3}{*}{ Bouyoucos (1951) } \\
\hline Silt (\%) & 8.0 & 36.0 & 8.0 & \\
\hline Clay (\%) & 69.6 & 53.6 & 49.6 & \\
\hline $\mathrm{pH}$ & 6.71 & 6.43 & 6.63 & Jackson (1958) \\
\hline $\mathrm{EC}\left(\mathrm{dS} \mathrm{m}^{-1}\right)$ & 0.18 & 0.11 & 0.62 & Jackson (1973) \\
\hline Organic carbon (\%) & 0.018 & 0.09 & 0.36 & Walkley and Black (1947) \\
\hline$N\left(\mathrm{~kg} \mathrm{ha}^{-1}\right)$ & 110.4 & 115.3 & 231.2 & Subbiah and Asija (1956) \\
\hline $\mathrm{P}_{2} \mathrm{O}_{5}\left(\mathrm{~kg} \mathrm{ha}^{-1}\right)$ & 72.6 & 277.4 & 280.3 & Bray and Kurtz (1945) \\
\hline $\mathrm{K}_{2} \mathrm{O}\left(\mathrm{kg} \mathrm{ha}^{-1}\right)$ & 358.7 & 348.9 & 598.4 & Muhr et al. (1965) \\
\hline
\end{tabular}

Table 3 Effect of treatments on organic carbon and change in carbon pool at $30 \mathrm{DAS}$, and earthworm count $\mathrm{m}^{-3}$ and nematode $\mathrm{g}^{-1}$ of rhizospheric substrates at 40 DAS of rice 


\begin{tabular}{|c|c|c|c|c|c|c|}
\hline \multirow[t]{2}{*}{$\begin{array}{l}\text { Treatment } \\
\text { combinations }\end{array}$} & \multirow[t]{2}{*}{$\begin{array}{l}\text { Sl. } \\
\text { No. }\end{array}$} & \multirow[t]{2}{*}{$\begin{array}{l}\text { Organic } \\
\text { C (\%) at } \\
30 \text { DAS }\end{array}$} & \multirow{2}{*}{$\begin{array}{l}\text { Change in } \\
\text { carbon pool } \\
\text { (mg of } \mathrm{C} \mathrm{kg}^{-} \\
\left.{ }^{1} \mathrm{month}^{-1}\right) \\
\text { at } 30 \mathrm{DAS}\end{array}$} & \multirow{2}{*}{$\begin{array}{l}\text { Earthworm count } \mathrm{m}^{-} \\
3 \text { of rhizospheric } \\
\text { substrate at } 40 \text { DAS }\end{array}$} & \multicolumn{2}{|c|}{$\begin{array}{l}\text { Nematode } \mathrm{g}^{-1} \text { of } \\
\text { substrate at } 40 \text { DAS }\end{array}$} \\
\hline & & & & & $\begin{array}{l}\text { Rhabditis } \\
\text { terricola }\end{array}$ & $\begin{array}{l}\text { Dorylaimida } \\
\text { sps }\end{array}$ \\
\hline$S_{0} F_{0} V_{100}$ & 1 & $\begin{array}{l}0.306 \pm \\
0.021\end{array}$ & $\begin{array}{l}-226.1 \pm \\
13.6\end{array}$ & $314.2 \pm 108.9$ & $\begin{array}{l}32.3 \pm \\
8.5\end{array}$ & $4.3 \pm 1.5$ \\
\hline $\mathrm{S}_{0} \mathrm{~F}_{20} \mathrm{~V}_{80}$ & 2 & $\begin{array}{l}0.45 \pm \\
0.027\end{array}$ & $\begin{array}{l}738.8 \pm \\
44.3\end{array}$ & $0.0 \pm 0.0$ & $\begin{array}{l}18.3 \pm \\
3.1\end{array}$ & $2.3 \pm 1.5$ \\
\hline $\mathrm{S}_{0} \mathrm{~F}_{40} \mathrm{~V}_{60}$ & 3 & $\begin{array}{l}0.375 \pm \\
0.03\end{array}$ & $\begin{array}{l}843.1 \pm \\
50.6\end{array}$ & $0.0 \pm 0.0$ & $\begin{array}{l}17.7 \pm \\
3.1\end{array}$ & $0.0 \pm 0.0$ \\
\hline $\mathrm{S}_{0} \mathrm{~F}_{60} \mathrm{~V}_{40}$ & 4 & $\begin{array}{l}0.288 \pm \\
0.02\end{array}$ & $\begin{array}{l}669.4 \pm \\
46.9\end{array}$ & $0.0 \pm 0.0$ & $\begin{array}{l}10.3 \pm \\
3.1\end{array}$ & $0.0 \pm 0.0$ \\
\hline $\mathrm{S}_{0} \mathrm{~F}_{80} \mathrm{~V}_{20}$ & 5 & $\begin{array}{l}0.252 \pm \\
0.01\end{array}$ & $\begin{array}{l}972.5 \pm \\
38.9\end{array}$ & $0.0 \pm 0.0$ & $9.3 \pm 2.5$ & $0.0 \pm 0.0$ \\
\hline $\mathrm{S}_{0} \mathrm{~F}_{100} \mathrm{~V}_{0}$ & 6 & $\begin{array}{l}0.054 \pm \\
0.003\end{array}$ & $\begin{array}{l}-357.9 \pm \\
21.5\end{array}$ & $0.0 \pm 0.0$ & $0.0 \pm 0.0$ & $0.0 \pm 0.0$ \\
\hline $\mathrm{S}_{20} \mathrm{~F}_{0} \mathrm{~V}_{80}$ & 7 & $\begin{array}{l}0.288 \pm \\
0.023\end{array}$ & $-16.2 \pm 0.8$ & $1067.2 \pm 287.7$ & $\begin{array}{l}23.3 \pm \\
2.3\end{array}$ & $8.3 \pm 2.1$ \\
\hline $\mathrm{S}_{20} \mathrm{~F}_{20} \mathrm{~V}_{60}$ & 8 & $\begin{array}{l}0.36 \pm \\
0.025\end{array}$ & $\begin{array}{l}849.6 \pm \\
59.5\end{array}$ & $250.8 \pm 108.6$ & $4.3 \pm 0.4$ & $2.3 \pm 0.6$ \\
\hline $\mathrm{S}_{20} \mathrm{~F}_{40} \mathrm{~V}_{40}$ & 9 & $\begin{array}{l}0.288 \pm \\
0.02\end{array}$ & $\begin{array}{l}863.9 \pm \\
60.5\end{array}$ & $0.0 \pm 0.0$ & $2.7 \pm 0.6$ & $0.0 \pm 0.0$ \\
\hline $\mathrm{S}_{20} \mathrm{~F}_{60} \mathrm{~V}_{20}$ & 10 & $\begin{array}{l}0.234 \pm \\
0.016\end{array}$ & $\begin{array}{l}1034.6 \pm \\
41.4\end{array}$ & $0.0 \pm 0.0$ & $3.3 \pm 1.5$ & $0.0 \pm 0.0$ \\
\hline $\mathrm{S}_{20} \mathrm{~F}_{80} \mathrm{~V}_{0}$ & 11 & $\begin{array}{l}0.036 \pm \\
0.003\end{array}$ & $\begin{array}{l}-420.8 \pm \\
33.7\end{array}$ & $0.0 \pm 0.0$ & $0.0 \pm 0.0$ & $0.0 \pm 0.0$ \\
\hline $\mathrm{S}_{40} \mathrm{~F}_{0} \mathrm{~V}_{60}$ & 12 & $\begin{array}{l}0.36 \pm \\
0.025\end{array}$ & $\begin{array}{l}840.9 \pm \\
58.9\end{array}$ & $501.5 \pm 108.6$ & $\begin{array}{l}24.3 \pm \\
6.0\end{array}$ & $10.3 \pm 4.2$ \\
\hline $\mathrm{S}_{40} \mathrm{~F}_{20} \mathrm{~V}_{40}$ & 13 & $\begin{array}{l}0.36 \pm \\
0.025\end{array}$ & $\begin{array}{l}1433.3 \pm \\
100.3\end{array}$ & $0.0 \pm 0.0$ & $\begin{array}{l}12.3 \pm \\
3.8\end{array}$ & $8.3 \pm 3.2$ \\
\hline $\mathrm{S}_{40} \mathrm{~F}_{40} \mathrm{~V}_{20}$ & 14 & $\begin{array}{l}0.216 \pm \\
0.015\end{array}$ & $\begin{array}{l}897.3 \pm \\
44.9\end{array}$ & $0.0 \pm 0.0$ & $6.3 \pm 2.1$ & $2.3 \pm 2.5$ \\
\hline $\mathrm{S}_{40} \mathrm{~F}_{60} \mathrm{~V}_{0}$ & 15 & $\begin{array}{l}0.036 \pm \\
0.003\end{array}$ & $\begin{array}{l}-495.9 \pm \\
34.7\end{array}$ & $0.0 \pm 0.0$ & $0.0 \pm 0.0$ & $0.0 \pm 0.0$ \\
\hline $\mathrm{S}_{60} \mathrm{~F}_{0} \mathrm{~V}_{40}$ & 16 & $\begin{array}{l}0.36 \pm \\
0.029\end{array}$ & $\begin{array}{l}1554.6 \pm \\
124.4\end{array}$ & $627.9 \pm 108.8$ & $8.3 \pm 3.5$ & $5.0 \pm 2.6$ \\
\hline $\mathrm{S}_{60} \mathrm{~F}_{20} \mathrm{~V}_{20}$ & 17 & $\begin{array}{l}0.288 \pm \\
0.02\end{array}$ & $\begin{array}{l}1849.7 \pm \\
129.5\end{array}$ & $124.4 \pm 107.8$ & $2.7 \pm 1.5$ & $2.3 \pm 2.1$ \\
\hline
\end{tabular}




\begin{tabular}{|c|c|c|c|c|c|c|}
\hline $\mathrm{S}_{60} \mathrm{~F}_{40} \mathrm{~V}_{0}$ & 18 & $\begin{array}{l}0.028 \pm \\
0.002\end{array}$ & $\begin{array}{l}-250.5 \pm \\
20.0\end{array}$ & $0.0 \pm 0.0$ & $0.0 \pm 0.0$ & $0.0 \pm 0.0$ \\
\hline $\mathrm{S}_{80} \mathrm{~F}_{0} \mathrm{~V}_{20}$ & 19 & $\begin{array}{l}0.108 \pm \\
0.005\end{array}$ & $\begin{array}{l}236.1 \pm \\
11.8\end{array}$ & $0.0 \pm 0.0$ & $\begin{array}{l}24.7 \pm \\
4.9\end{array}$ & $0.0 \pm 0.0$ \\
\hline $\mathrm{S}_{80} \mathrm{~F}_{20} \mathrm{~V}_{0}$ & 20 & $\begin{array}{l}0.027 \pm \\
0.002\end{array}$ & $-78.1 \pm 3.1$ & $0.0 \pm 0.0$ & $\begin{array}{l}15.7 \pm \\
3.2\end{array}$ & $0.0 \pm 0.0$ \\
\hline $\mathrm{S}_{100} \mathrm{~F}_{0} \mathrm{~V}_{0}$ & 21 & $\begin{array}{l}0.018 \pm \\
0.001\end{array}$ & $0.0 \pm 0.0$ & $0.0 \pm 0.0$ & $\begin{array}{l}22.3 \pm \\
3.5\end{array}$ & $1.3 \pm 0.6$ \\
\hline S.Em $( \pm)$ & & 0.087 & 0.011 & 33.0 & 1.9 & 0.9 \\
\hline C.D. $(0.05)$ & & 0.247 & 0.031 & 94.1 & 5.5 & 2.7 \\
\hline
\end{tabular}

\section{Figures}

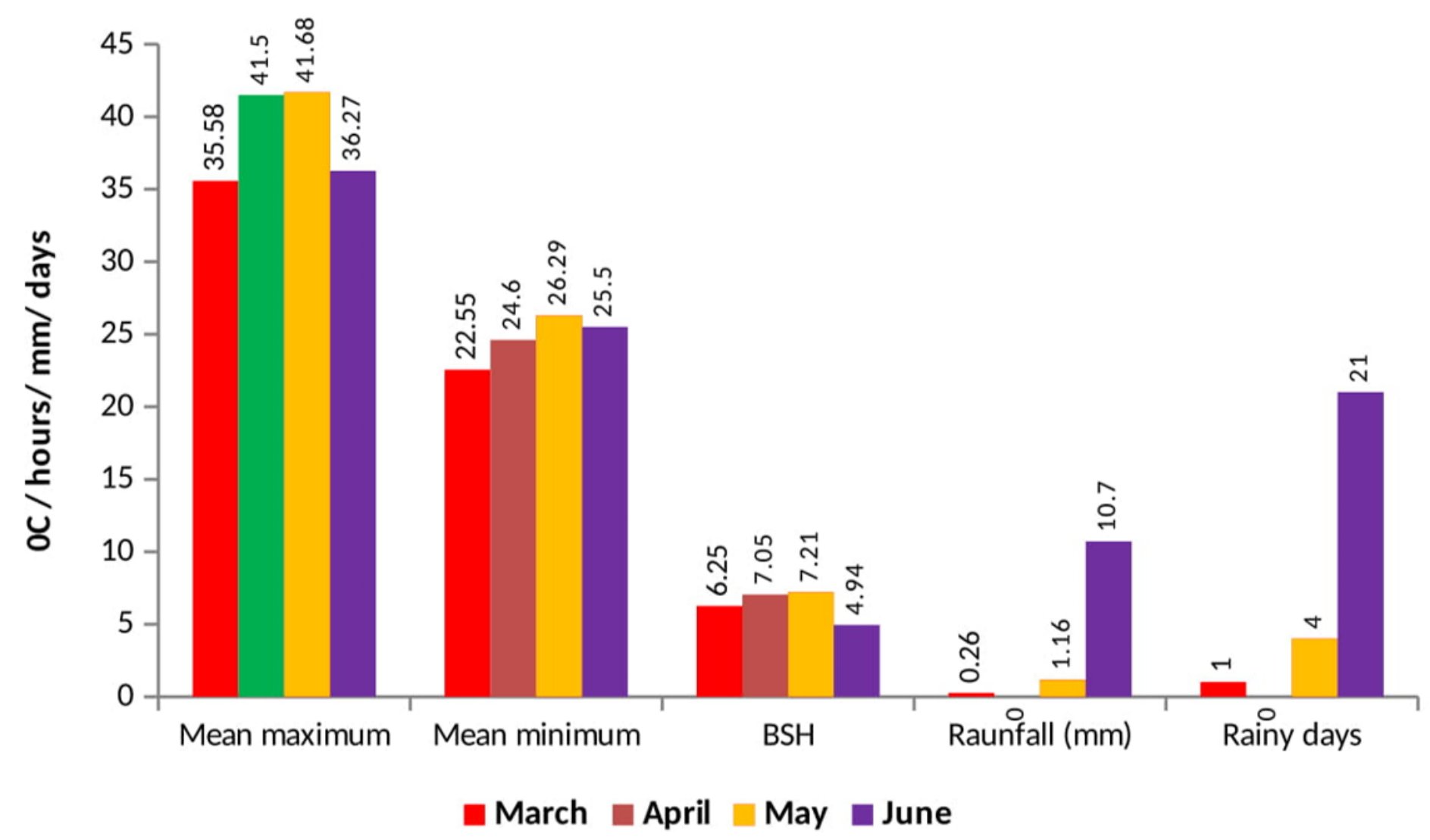

Figure 1

Meteorological parameters of the experimental site during March to June 2017 


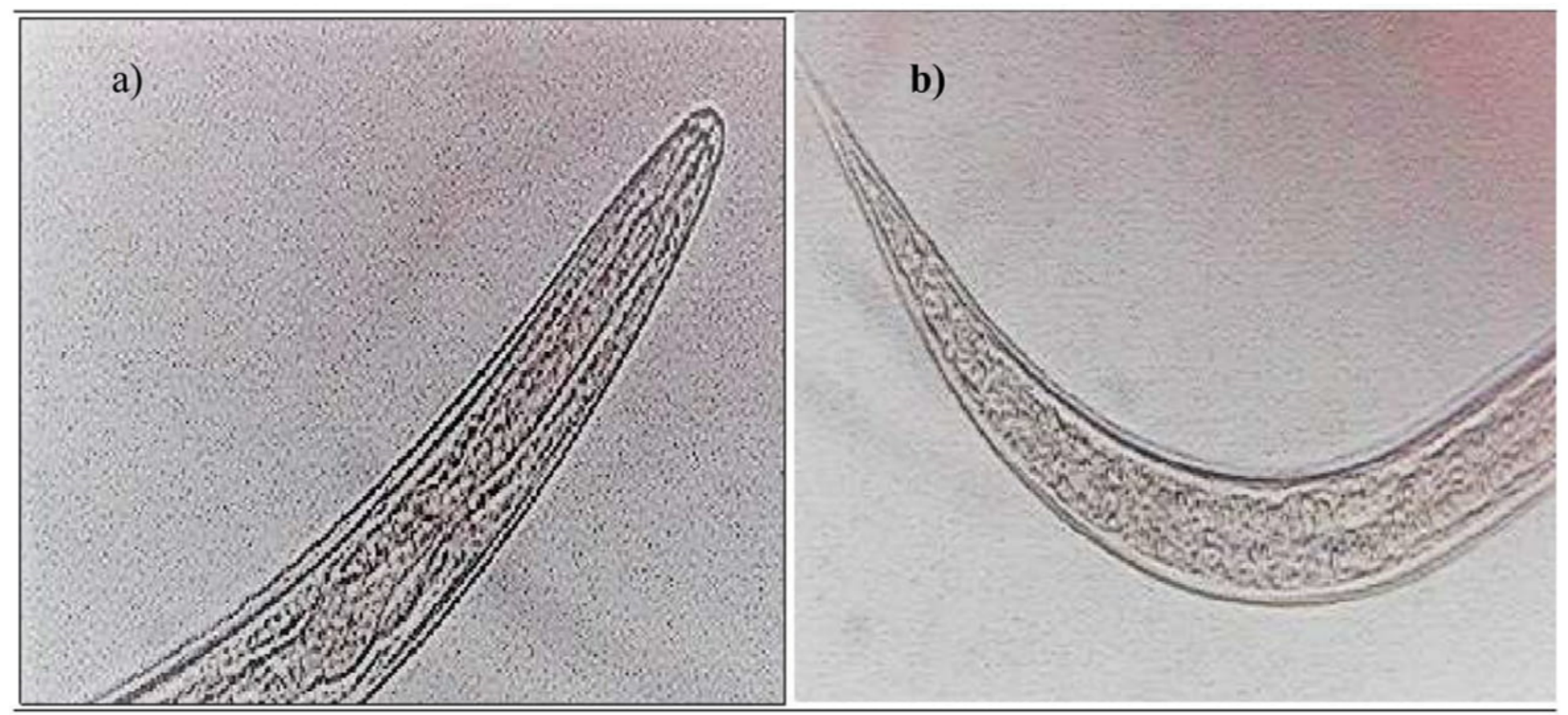

\section{Figure 2}

a) Anterior and b) posterior part of Rhabditid under trinocular microscope

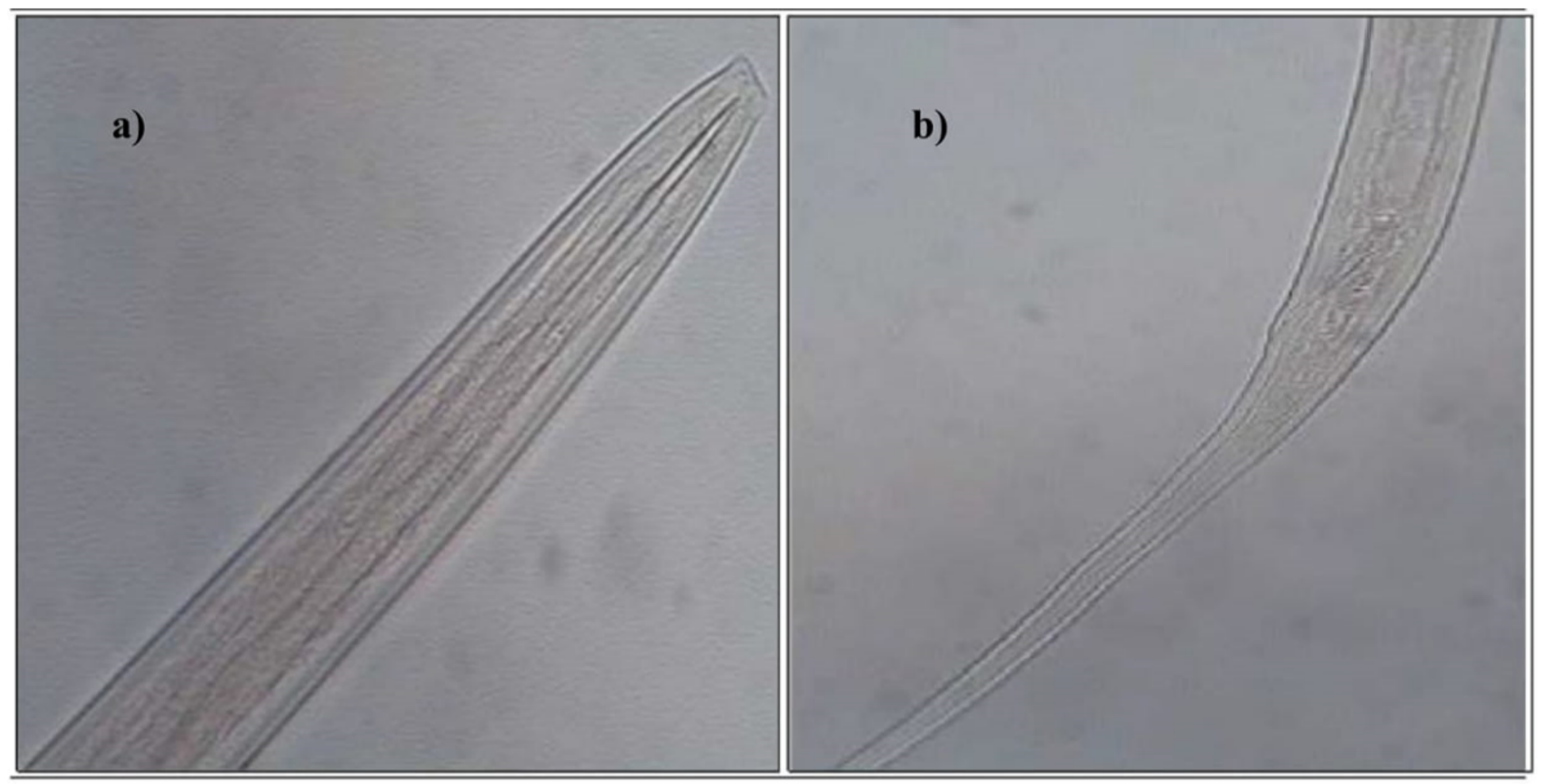

Figure 3

a) Anterior and b) posterior part of Dorylaimid under trinocular microscope 


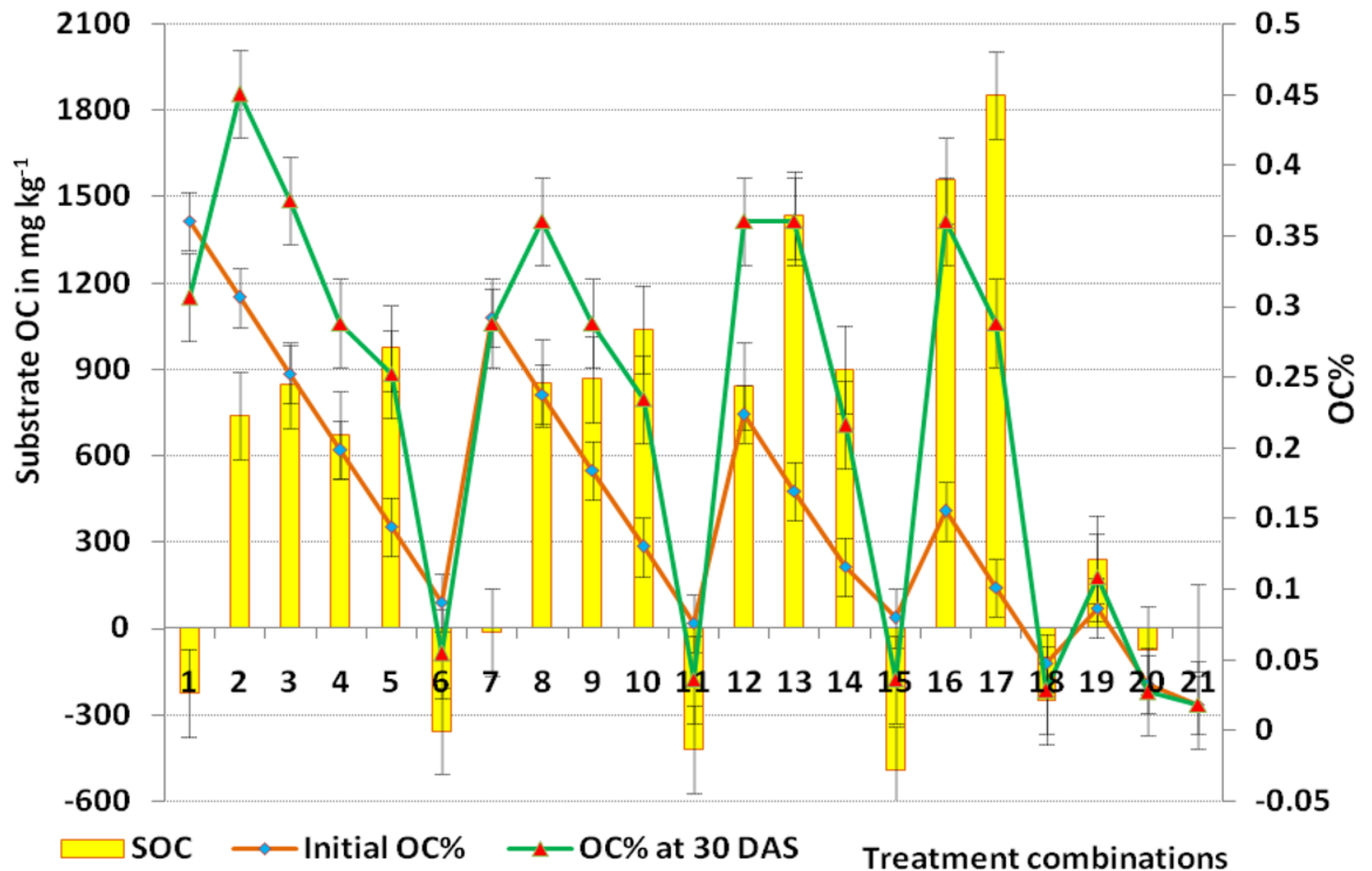

Figure 4

Variations in substrate organic carbon (SOC), OC\% between initial and 30 DAS as influenced by treatment combinations in rice nursery (vertical bars indicate standard errors) (1: SOFOV100, 2: SOF20V80, 3:

SOF40V60, 4: SOF60V40, 5: SOF80V20, 6: SOF100V0, 7: S20F0V80, 8: S20F20V60, 9: S2OF40V40, 10: S20F60V20, 11: S20F80V0, 12: S40F0V60, 13: S40F20V40, 14: S40F40V20, 15: S40F60V0, 16: S60F0V40, 17: S60F20V20, 18: S60F40V0, 19: S80F0V20, 20: S80F20V0 and 21: S100F0V0) 